\title{
A Review on Infectious Bursal Disease - Major Concern in Poultry
}

\author{
Shashank Shekhar ${ }^{1 *}$ and Nirupama Dalai ${ }^{2}$ \\ ${ }^{1}$ Venkey's (India) Ltd., Bhubaneswar, Odisha, 751003, India \\ ${ }^{2}$ Department of Veterinary Physiology, \\ CVSc \& A.H.,OUAT, Bhubaneswar, Odisha, 751003, India \\ *Corresponding author
}

\section{Keywords \\ Infectious bursal disease, \\ Birnaviridae, \\ Haemorrhage, B lymphocyte}

\section{Article Info}

Accepted:

15 May 2020

Available Online:

10 June 2020

\section{A B S T R A C T}

Infectious bursal disease is an acute and highly contagious viral disease of mostly young chickens cause by a non-envelope double stranded RNA virus belonging to a family Birnaviridae and is the second considerable threat among infectious poultry diseases. The enormous economic losses associated with the disease is due to high mortality, decreased performance, immune supression that leads to increase susceptibility to other diseases and decrease response to vaccination. The target organ of infectious bursal disease virus (IBDV) is the bursa of fabricius at its maximum development, which is a specific source for B lymphocytes in avian species. The observed clinical signs during IBD infection include high mortality, unsteady gait, ruffled feathers, urate containing diarrhoea and sudden death. The post-mortem finding includes haemorrhages in the leg and breast muscles, enlarged, edematous and hyperaemic bursa with bloody or mucoid contents. RT-PCR/RFLP is a very useful and rapid method for characterization and identification of existing and evolving strains of IBDV. Only supportive therapy, immunobooster medicines with vaccination and maintaining bio securities may combat mortalities.

\section{Introduction}

The term poultry refers to rearing of chickens, ducks, geese, turkeys and domestic fowls. They are reared for their flesh, eggs and feathers. Poultry farming have been gaining much importance due to growing demand for poultry products as having high food values in terms of rich sources of protein, vitamins and minerals. Among the poultry products, chicken is the widely accepted meat in India and in the world and being used by the people regularly as a supplementary food.

Between 1970 and 2005 poultry meat and eggs increased faster than beef, veal and pig meat (Windhorst, 2006). Apart from lot of opportunities in this field there are some 
barriers as well in terms of climatic hazards, outbreak of bird flu, outbreak of different kinds of bacterial and viral diseases, vaccine failure if not proper maintaining cool chain, availability of good qualities food etc. Among these barriers one of the viral disease namely Infectious Bursal Disease (IBD) is havoc for poultry men (Siddique et al., 1987). This disease was discovered in town Gumboro (Cosgrove, 1962). IBD is the second considerable threat among infectious poultry diseases (Alexander, 1996). This disease is extremely contagious in infected flocks, morbidity is high, with up to 100 percent seroconversion after infection, whilst mortality is variable (van den Berg et al., 2000). The enormous economic losses associated with the disease is due to high mortality, decreased performance, immune supression that leads to increase susceptibility to other diseases and decrease response to vaccination (Abdu et al., 2001; Khan et al., 2007). Experts documented that IBD was one of the disease which was not affected by weather (Yunus et al., 2009). The incidence of IBD decreased with increase in flock size. This threat is at peak during third to fourth week of age (Sarfraz et al., 2017; Sultana et al., 2009; Yunus et al., 2008) and also up to sixth week, at which age the bursa of fabricius is at its peak of development where follicles are filled with immature lymphocytes (Mahgoub, 2012; Sharma et al., 2000; Baxandale, 1981; Khan et al., 2007).

\section{Etiology}

Infectious bursal disease otherwise known as Gumboro disease is an acute and highly contagious viral disease of mostly young chickens cause by a non-envelope double stranded RNA virus belonging to a family Birnaviridae (Hair-Bejo et al., 2004; Lukert and Saif, 1997). There are two distinct serotypes, namely 1 and 2 of infectious bursal disease virus (IBDV) have been reported
(Lukert and Saif, 1997), out of which only serotypes 1 has been associated with clinical disease, thereby all commercial vaccines available have been prepared against serotype 1 (OIE, 2008). The mortality is determined by multiple factors including the virulence of IBDV, the dose of infection, the age and breed of chickens and the passive immunity as well (Ingrao et al., 2013). Out of four existing pathotypes of serotype 1, very virulent IBD (vvIBDV) have been incriminated for most vaccination failure (Lukert and Saif, 1997), and causes mortality from $50 \%$ to $100 \%$ in young chickens (Annamalai et al., 2016; Stoute et al., 2013).

\section{Transmission and pathogenesis}

The selected host of the virus is young chickens where a clinical disease occurs, while in older birds the infection is essentially subclinical. It was found that light breeds showed higher mortality than the heavier breeds (Bumstead et al., 1993; Nielson et al., 1998). Moreover, the layer type chickens were more susceptible to vvIBDV than broiler-type chickens, both in conventional status and specific-pathogen-free status (Sa et al., 2016; Tippenhauer et al., 2013). Sultana et al., (2008) stated that this disease prevails around the year however stress factors enhances its occurrence in birds. In winter months the sheds were kept air tight to maintain temperature so the virus load increases inwards when the fresh air moves through shed ventilation system it becomes the vital source of aerosol infection in nearby sheds.

The target organ of IBDV is the bursa of fabricius at its maximum development, which is a specific source for B lymphocytes in avian species. After oral infection or inhalation, the virus replicates primarily in the lymphocytes and macrophages of the gutassociated tissues. Then virus travels to bursa 
through blood stream, where replication occurs. After 13 hours of post-inoculation most follicles are positive for virus and by 16 hours of same pronounced viraemia occurs with secondary replication in other organs leading to disease and death (Muller et al., 1979). IBDV also invades and replicates in the cells of monocytes-macrophage lineage in a persistent manner (Inoue et al., 1992), which impedes the phagocytic activity of macrophages and facilitates virus dissemination (Lam, 1998). Apart from these the virus can infect chicken bone marrowderived dendritic cells (Liang et al., 2015).

\section{Diagnosis and histopathology}

The observed clinical signs during IBD infection include high mortality, unsteady gait, ruffled feathers, urate containing diarrhoea and sudden death (Islam and Sabad, 2004; Rakibul Hasan et al., 2010). The postmortem finding includes haemorrhages in the leg and breast muscles, enlarged, edematous and hyperaemic bursa with bloody or mucoid contents or atrophic in chronic cases and haemorrhage in the junction between gizzard and proventriculus. Presence of gelatinous exudates in the serosa of bursa and occasionally atrophied bursa which sometimes contained cheesy mass in the lumen was also noticed. In addition dehydration and nephrosis with swollen kidneys are common (Islam and Sabad, 2004; Chowdhury et al., 1996; Okoye, 1984).

Severe depletion of lymphoid cells is observed not only in the bursa of fabricius but also in the non-bursa lymphoid tissues (Thierry, 2000). Using various immuno staining methods, a higher frequency of antigen-positive cells could be demonstrated after infection of birds with vvIBDV compared with other strains, in the thymus (Inoue et al., 1999; Nunoya et al., 1992; Sharma et al., 1993) the spleen and the bone marrow (Inoue et al, 1999; Tanimura et al., 1995). Sharma et al., (1993) also investigated that atrophy of the thymus has been associated with the acute phase of the disease and might be indicative of the virulence of the isolate. Thrombocytes also represent a target for IBDV, and acute disease is characterized by disseminated haemorrhages probably related to an impairment of the clotting mechanism (Skeeles et al., 1980). Laboratory diagnosis of IBDV by inoculation in avian embryo through chorio-allantoic membrane (CAM) route is the effective tool where thickened CAM, congested and haemorrhagic dead embryos along the feather tracts, toe and cerebral area is noticed (Rakibul Hasan et al., 2010; Takase et al., 1996). The positive results has been obtained by using molecular methods for detection of IBDV through Agar gel immune diffusion test (AGIDT) by (Gupa et al., 2001; Karunakaran et al., 1993; Muhammad et al., 1996; Shekaro, 2015) and RT-PCR using IBD virus specific primers by (Banda et al., 2001; Hemandez et al., 2006). RT-PCR/RFLP is a very useful and rapid method for characterization and identification of existing and evolving strains of IBDV (Zahoor et al., 2011).

\section{Control and treatment}

As it is a viral disease, there is no effective remedy as such but through control measures supportive therapy mortality can be reduced. Haddad et al., (1997) stated that 1-day-ofage-administered IBDV-BDA complex vaccine can induce active immunity and protection against a standard IBDV challenge in the face of variable levels of maternal IBDV immunity. Similarly the role of cellmediated immunity in pathogenesis of IBD was stated by Yeh et al., (2002) and they concluded that under normal conditions, IBDV induces a protective antibody response; however, in the absence of antibody, CMI alone is adequate in protecting birds against 
virulent IBDV. Thee multivitamin therapy along with vaccination showed boosting effects in protection. IBD strain D-78 caused low stress with good protective titre in the birds (Khan et al., 2003). The comparative immune stimulatory studies of two available market products i-e Livol (herbal supplement) and immuno tone (selenium and vit E) by ELISA were noted. Livol showed more encouraging results than immunotone to minimize the adverse effect of IBDV vaccine. Different immunogenic products were tried to select the better one available in commercial markets (Qayyum et al., 2012; Saleem and Mehmood, 2013; Zahid et al., 2015). It promoted immune status against IBD and result in better feed conversion ratio (Malik et al., 2006). VP2 from a virulent IBDV strain $52 / 70$ expressed as a $\beta$-galactosidase fusion protein in a recombinant fowlpox virus, fpIBD 1, provided protection against mortality, but not against damage to the bursa of fabricious (Bayliss et al., 1991). A novel complex IBDV vaccine containing a mixture of IBDV with viral antibodies (bursal disease antibody; BDA) has been evaluated for safety and protection of chicks following subcutaneous administration (Whitfill et al., 1995). Apart from these some preventive measures includes:

The premises and equipment should be cleaned and disinfected regularly.

Dead birds need to be well disposed

Wild birds and rodents should be excluded in and around the farm.

Arrangement of foot bath at the entry of farm.

Day to day morbidity and mortality records should be maintained.

Infectious bursal disease commonly observed in chicks during 3-6 weeks of age hampering immune status of the host. The main reason for occurrence is improper vaccination administration, poor vaccine handling, poor management and bio security in the farm etc which counts for economic losses. Only supportive therapy, immunobooster medicines with vaccination may combat mortalities along with good bio security measures can improve economic status of farmers by reducing morbidity and mortality costs.

\section{References}

Abdu, P.A. , Umoh, J.U. , Abdullhi, S.U. and Sa'idu, L. 2001. Infectious bursal disease in chickens in Nigeria. Trop. Vet, 19(4): 216-236.

Alexander, D. 1996. Newcastle Disease Manual of Standards for Diagnostic Tests and Vaccines. Office International des Epizooties, Paris.

Annamalai, A, Ramakrishnan, S, Sachan, S, Kumar, B.S., Sharma, B.K., Kumar, V., Palanivelu, M, Varghese, B.P., Kumar, A. and Saravanan, B.C. 2016. Prophylactic potential of resiquimod against very virulent infectious bursal disease virus (vvIBDV) challenge in the chicken. Vet. Microbiol, 187: 21-30.

Banda, A, Villegas, P, El-Attrache, J and Estevez, C. 2001. Molecular characterization of seven field isolates of infectious bursal disease virus obtained from commercial broiler chickens. Avian Disease, 45(3): 620-30.

Baxendale W. 1981. Immunity to infectious bursal disease. In: Avian Immunology. Rose ME, Payne LV and Freeman BM, Eds. Edinb. Br. Poult. Sci. Ltd, 225227.

Bayliss, C.D., Peters, R.W., Cook, J.K.A., Reece, R.L., Howes, K., Binns, M.M. and Boursnell, MEG. 1991. A recombinant fowlpox virus that expresses the VP2 antigen of infectious bursal disease virus induces protection against mortality caused by the virus. Arch Virol, 120: 193-205.

Bumstead N, Reece RL and Cook JKA. 1993. 
Genetic differences in susceptibility of chicken lines to infection with infectious bursal disease virus. Poultry Science, 72: 403-410.

Chowdhury EH, Islam MR, Das PM, Dewan ML and Khan MSR. 1996. AJAS, 9(4): 465-469.

Cosgrove, A. 1962. An apparently new disease of chickens: avian nephrosis. Avian Dis, 6: 385-389.

Gupta, AK, Oberoi, M.S. and Maiti, N.K. 2001. Detection of infectious bursal disease virus strains of varying pathogenicity under field conditions. Indian Journal of Comparative Microbiology, Immunology and Infectious diseases, 22: 26-28.

Haddad, E.E, Whitfill, C.E., Avaskin, A.P., Ricks, C.A., Andrews, P.D., Thoma, J.A. and Wakenell, P.S. 1997. Efficacy of novel infectious bursal disease virus immune complex vaccine in broiler chickens. Avian Dis, 41(4): 882-889.

Hair-Bejo, M., Ng, M.K. and Ng, H.Y. 2004. Day Old Vaccination against Infectious Bursal Disease in Broiler Chickens. Int. J. Poult. Sci, 3(2): 124-128.

Hernandez, M., Banda, A., Hernandez, D., Panzera, F. and Perez, R. 2006. Detection of very virulent strains of infectious bursal disease virus (vvIBDV) in commercial broilers from Uruguay. Avian Disease, 50(4): 624-31.

Ingrao, F, Rauw, F, Lambrecht, B and van den Berg T. 2013. Infectious Bursal Disease: A complex host-pathogen interaction. Dev. Comp. Immunol, 41: 429-438.

Inoue, M., Fujita, A. and Maeda, K. 1999. Lysis of myelocytes in chickens infected with infectious bursal disease virus. Veterinary Pathology, 36: 146151.

Inoue, M., Fukuda, M. and Miyano, K. (1994). Thymic lesions in chicken infected with infectious bursal disease virus. Avian Diseases, 38: 839- 846.

Inoue, M., Yamamoto, H., Matuo, K. and Hihara, H. (1992). Susceptibility of chicken monocytic cell lines to infectious bursal disease virus. J. Vet. Med. Sci, 54: 575-577.

Islam, M.T. and Samad, M.A. 2004a. Clinicopathological studies on natural and experimental infectious bursal disease in broiler chickens. Bangladesh Journal of Veterinary Medicine, 2: 31-35.

Karunakaran, K., Thanappapilldi, M. and Raghavan, N. 1993. Seroprevalence of Infectious Bursal Disease (IBD) in parts of Tamil Nadu, India. Comparative Microbiology, Immunology and Infectious disease, 16: 241-244.

Khan, M.A., Siddique, M., Hassan, I., Rahman, S.U. and Arshad, M. 2007. Adaptation of local wild infectious bursal disease virus in chicken embryo fibroblast cell culture. Int. J. Agri. Biol, 9(6): 925-927.

Khan, S.A., Aslam, A., Muhammad, K. and Khan, K.A. 2003. Effect of post vaccination on medication on layer chicks vaccinated with Gumboro Vaccine Nobilis D-78. Pakistan Veterin. J, 23: 192-196.

Lam, K.M. 1998. Alteration of chicken heterophil and macrophage functions by the infectious bursal disease virus. Microb. Pathog, 25: 147-155.

Liang, J., Yin, Y, Qin, T. and Yang, Q. 2015. Chicken bone marrow-derived dendritic cells maturation in response to infectious bursal disease virus. Vet. Immunol. Immunopathol, 164: 51- 55.

Lukert, P.D. and Saif, Y.M. 1997. Infectious bursal disease. In: Diseases of poultry, Calnek BW, Barnes HJ, Beard CW, McDougald LR and th Saif YM, Eds. 10 Ed. Iowa State Univ. Press., 721735.

Mahgoub, H.A. 2012. An overview of infectious bursal disease. Arch. Virol, 
157: 2047-2057.

Malik, M.W., Ayub, N. and Qureshi, I.Z. 2006. Passive immunization using purified IgYs against infectious bursal disease of chickens in Pakistan. J. Vet. Sci, 7: 43-46.

Muhammad, K., Muneer, A., Anwer, M.S. and Yaqub, M.T. 1996. Failure of vaccines to control infectious bursal disease in commercial poultry. Pakistan Veterinary Journal, 16: 119-121.

Muller, R., Kaufer, I., Reinacher, M. and Weiss, E. 1979. Immunofluorescent studies of early virus propagation after oral infection with infectious bursal disease virus (IBDV). Zentralblad Veterinarmedicine [B], 26: 345-352.

Nielsen, O.L., Sorensen, P., Hedemand, J.E., Laursen, S.B. and Jorgensen, P.H. 1998. Inflammatory response of different chicken lines and B haplotypes to infection with infectious bursal disease virus. Avian Pathology, 27: 181-189.

Nunoya, T., Otaki, Y., Tajima, M., Hiraga, M. and Saito, T. 1992. Occurrence of acute infectious bursal disease with high mortality in Japan and pathogenicity of field isolates in SPF chickens. Avian Diseases, 36: 597-609.

Office International des Epizooties. 2008. Infectious bursal disease. Terr. Manual, 555-557.

Okoye, JOA. 1984. Infectious bursal disease of chickens. Vet. Bull, 54: 425-436.

Qayyum, A., Yousaf, A., Ahmad, T., Rehman, Z. and Farooq, U. 2012. Immunomodulatory effects of Lisovitin response to Newcastle disease and infectious bursal disease vaccines in broilers. J. Anim. Plant Sci, 22: 11-14.

Rakibul Hasan, A.K.M., Ali, M.H., Siddique, M.P., Rahman, M.M. and Islam, M.A. 2010. Clinical and laboratory diagnosis of Newcastle and Infectious Bursal Disease of chickens. Bangl. J. Vet. Med, 8(2): 131-140.
Sa, E.S.M., Rissi, D.R. and Swayne, D.E 2016. Very Virulent Infectious Bursal Disease Virus Produces More-Severe Disease and Lesions in SpecificPathogen-Free (SPF) Leghorns Than in SPF Broiler Chickens. Avian Dis, 60: 63-66.

Saleem, M.H. and Mehmood, K. 2013. Effect of a herbal supplement Livol on the growth performance and antibody response against infectious bursal disease virus in broiler chicks. Pakistan J. Zool, 45: 1387-1391.

Sarfraz, M., Ashraf, Y. and Ashraf, S. 2017. A Review: Prevalence and antimicrobial susceptibility profile of listeria species in milk products. Matrix Sci. Medica, 1(1): 03-09.

Sharma, J.M., Dohms, J., Walser, M. and Snyder, D.B. 1993. Presence of lesions without virus replication in the thymus of chickens exposed to infectious bursal disease virus. Avian Diseases, 37: 741748.

Sharma, J.M., Kim, I., Rautenschlein, S. and Yeh, H. 2000. Infectious bursal disease virus of chickens: Pathogenesis and immunosuppression. Dev. Comp. Immunol, 24: 223-235.

Shekaro, A. 2015. Infectious bursal disease outbreak in fifteen weeks old pullets in Kaduna, Nigeria. J Anim Pro Adv, 5(3): 636-644.

Siddique, M.T., Javed, T. and Sabri, M. 1987. Incidence and pathogenesis of various poultry diseases prevalent in Faisalabad and surrounding districts. Pakistan Vet. J, 7: 148-154.

Skeeles, J.K., Slavik, M., Beasley, J.N., Brown, A.H., Meinecke, C.F., Maruca, S. and Welch, S. 1980. An age-related coagulation disorder associated with experimental infection with infectious bursal disease virus. American Journal of Veterinary Research, 41: 1458-1461.

Stoute, S.T., Jackwood, D.J., Sommer- 
Wagner, S.E., Crossley, B.M., Woolcock, P.R. and Charlton, B.R. 2013. Pathogenicity associated with coinfection with very virulent infectious bursal disease and Infectious bursal disease virus strains endemic in the United States. J. Vet. Diagn. Investig, 25: 352-358.

Sultana, R., Ilyas, S., Anjum, A., Zaidi, R. and Hussain, F. 2008. Epidemiology of Infectious Bursal Disease in Broilers in and around Lahore. Pakistan J. Zool, 23: 067-072.

Takase, K., Baba, G.M., Ariyoshi, R. and Fujikawa, H. 1996. Susceptibility of chicken embryos to highly virulent infectious bursal disease virus. Journal of Veterinary Medical Science, 58: 1129-1131.

Tanimura, N., Tsukamoto, K., Nakamura, K., Narita, M. and Maeda, M. 1995. Association between pathogenicity of Infectious Bursal Disease Virus and viral antigen distribution detected by immunochemistry. Avian Diseases, 39: 9-20.

Thierry P van den Berg. 2000. Acute infectious bursal disease in poultry: a review. Avian Pathology, 175-194.

Tippenhauer, M., Heller, D.E., Weigend, S. and Rautenschlein, S. 2013. The host genotype influences infectious bursal disease virus pathogenesis in chickens by modulation of $\mathrm{T}$ cells responses and cytokine gene expression. Dev. Comp. Immunol, 40: 1-10.

Van den Berg TP. 2000. Acute infectious bursal disease in poultry. Rev. Avian
Pathol, 29: 175-193.

Whitfill, C.E., Hadda, E.E., Ricks, C.A., Skeeles, J.K. and Newberry, L.A., Beasley, J.N., Andrews, P.D., Thoma, J.A. and Wakenell, P.S. 1995. Determination of optimum formulation of a novel infectious bursal disease virus (IBDV) vaccine constructed by mixing bursal disease antibody with IBDV. Avian Dis, 39: 687-699.

Windhorst, H.,W. 2006. Changes in poultry production and trade worldwide. World's Poultry Science Journal, 62: 588.

Yeh, H.Y., Rautenschlein, S. and Sharma, J.M. 2002. Protective immunity against infectious bursal disease virus in chickens in the absence of virus-specific antibodies. Vet Immunol Immunopathol, 89(3-4): 149-158.

Yunus, A., Nasir, M., Aziz, T. and Böhm, J. 2009. Prevalence of poultry diseases in district chakwal and their interaction with mycotoxicosis: 2. Effects of season and feed. J. Anim. Plant Sci, 19: 1-5.

Zahid, B., Saleem, G., Aslam, A., Imran, M. and Younas, M. 2015. Effect of immunostimulants on humoral response against infectious bursal disease in broilers. Pakistan Veterin. J, 35: 227230.

Zahoor, M., Abubakar, M., Naim, S., Khan, Q.and Arshed, M. 2011. Molecular Typing of Field Isolates from two outbreaks of Infectious Bursal Disease Virus from Pakistan. Veterinary World, 4: $297-300$

\section{How to cite this article:}

Shashank Shekhar and Nirupama Dalai. 2020. A Review on Infectious Bursal Disease - Major Concern in Poultry. Int.J.Curr.Microbiol.App.Sci. 9(06): 535-541. doi: https://doi.org/10.20546/ijcmas.2020.906.069 